\title{
WINNERS AND LOSERS IN POST COVID-19 BUSINESS WORLD, THE NEW NORM FOR MALAYSIA
}

\author{
${ }^{1}$ Karthigayan Gunasegaran, ${ }^{2}$ Che Zalina Zulkifli, ${ }^{3}$ Sivaganesh Loganathan, ${ }^{4}$ Mohd Fauzi Sedon \\ Sultan Idris Education University, Malaysia \\ Email: ${ }^{1}$ karthigayan.guna@thinkcity.com.my, ${ }^{2}$ chezalina@fskik.upsi.edu.my, \\ ${ }^{4}$ mohd.fauzi@fskik.upsi.edu.my
}

\begin{abstract}
Purpose: The purpose of this study is to explore and analysis winners and losers in post covid-19 business world, the new norm for Malaysia.

Design/methodology/approach: This study uses a literature research model, which is to collect various kinds of data and literature then take the essence of the data and literature then describe and analyze it.

Findings: COVID-19 pandemic manifested at the time when mankind was least prepared to face it. This virus has permanently altered the fabric of the globalized world. The global damages inflicted by this pandemic go beyond loss of lives in multitudes, but also quality of living. While government around the world are battling to contain the virus for the safety of its people, there is a pressing need to start thinking about a world that will be living with the after effects of COVID-19.The global economy is going to shrink drastically and Malaysia will not be spared. The damage will be irreversible should all measures to contain the virus fail. Taking into account various scenario modeling from credible sources, a list of winners and losers in post COVID-19 business world has been derived. The reality of this pandemic demands the business world to embark on an accelerated shift towards being innovative, digital, pro-active and pre-emptive.
\end{abstract}

Research limitations/implications: This research uses secondary data.

Practical implications: Business entities can use the result of research as consideration so that the business can still exist.

Originality/value: This research explores the phenomena of covid 19 in Malaysia and the impact on business.

Paper type: Research paper.

Keyword: Business, COVID-19, Government, Winner, Losser

Received: August $17^{\text {th }}, 2020$

Revised: September $18^{\text {th }}, 2020$

Published: September $30^{\text {th }}, 2020$

\section{INTRODUCTION}

Not till early-April 2020 did MakCikKiah, Madam Lee, Madam SurjitKaur and Haji Sallehunderstand the true meaning of a pandemic. This common understanding came as a rude shock not just to them buthumankind as a whole regardless of socio-economical, geo-political or education background. COVID-19 single-handedly brought theworld to a standstill, something that was last experienced 80 years agoduring WWII (WHO, 2020). Government around the world are investing in tools and technologies to save lives now, in contrast to destroy then. However, this approach is a total stranger to the world that had its focus on foreign military threat than a self-inflicted pandemic.COVID-19 has infected over 1.9 million people and claimed over 120,000 lives across 210 countries and territories as of mid-April 2020. World leaders are grappling to understand the pandemic. Failure to contain the virus and threat of a potential relapse are imminent. The current situate.ion is expected to stay for another 18 months at the very minimum (WHO, 2020). 
For an extended period of time; borders will stay closed or partially closed, people will stay under full or partial lockdown, physical distancing will continue and businesses will not revert to pre COVID-19 era. Social divide that steeply widened in just matter of weeks will only amplify moving forward (Dartnell, 2020).

While many governments have introduced stimulus packages to bolster the impact of the pandemic, they are merely reactionary and do not yield long term solution. With a viable vaccine still far from sight, governments around the world are grappling to make an informed decision in response to their newly emerged shared enemy. The situation is further aggravated by less informed citizens who fail to comply with Lockdown or any forms of Movement Restriction Order (MRO) to break Covid-19 transmission chain. This refusal and failure to comply will proof the global effort against the pandemic futile (Rayda, 2020).

Historical accounts show this may not be the last pandemic human race will ever face. As long as humans co-exist alongside other animals, cross infection in the animal kingdom that humans are part of is unavoidable (WHO, 2020). Coupled with genetic modification or engineering, whether intentionally or out of curiosity, will place pandemic as precursor for modern warfare. With that backdrop, it is essential to look at national, regional and global economic growth which will inform the immediate, short term and medium term growth impact of the pandemic across the business world.

\section{SYSTEMIC REVIEW}

\section{A. Global and Regional Economic Growth}

Covid-19 will pose major impact not just on China's economy but the world economy as a whole. Emerging markets such as Malaysia, Indonesia and Thailand will feel the excruciating pain of this impact (IMF, 2020).

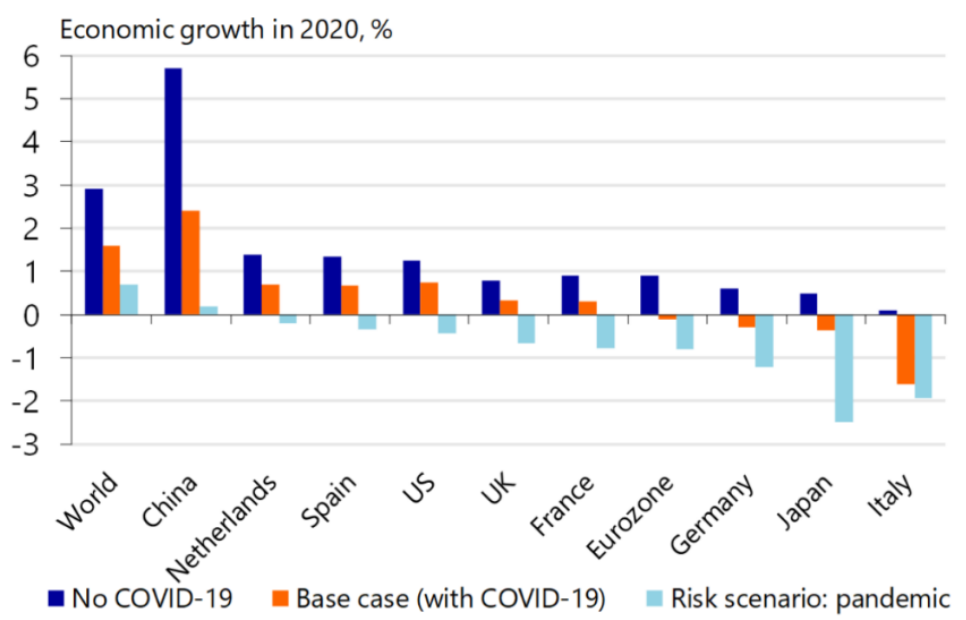

Figure 1. Economic Growth

China, the second biggest global economy, will be the biggest loserwith $3.7 \%$ slash in economic growth. Meanwhile Japan, the third biggest global economy, is projected to experience negative growth this year $(-0.4 \%)$. The shrinking economy of these two Asia giant will definitely pose threat to economy of Malaysia as they constitute $24 \%$ of Malaysia's export market (MATRADE, 2020). The world economic growth is projected to be slashed by nearly half of the 2019 (2.9\%) growth to $1.6 \%$ in 2020 , crawling to $3.2 \%$ in 2021. This will get worse should the pandemic extend (Erken, 2020).

A trading nation like Malaysia where the GDP is highly connected to global supply chain and grassroots business world will feel the economic contraction. World Bank reported economic recovery especially for Malaysian SME to take years due to disruption in the supply chain and demand (World Bank Group, 2020).

Volatility caused by this crisis will trickle down to the grassroots business with deterioration or disruption to cash flows and inability for liquidation. This situation will hit legacy industries or businesses that have been known to have strong fundamentals. The rise of abrupt sales of high and mid risk assets, bonds and commodities will further escalate the speed of the plumage. The situation will gravitate towards weakening of national reserve that will in turn make impact fiscal policy. The current quantitative easing embarked by the government may not be an optimal choice (Meier, 2009). 
Past pandemic with focus on China might be able to give a glimpse on the potential panning out of this crisis. The learning form past post-crisis economic pattern could enable Malaysia to be better prepared to buffer the calamity.

\section{B. Reflecting on China}

China has seen several major outbreaks in the last 2 decades. All these have had impact on its economy and selected sectors. However, the closest to Covid-19 would be SARS outbreak between 2002 and 2003 (Han, Harris and Luedi, 2020).

Impact of past epidemics on China's annual GDP

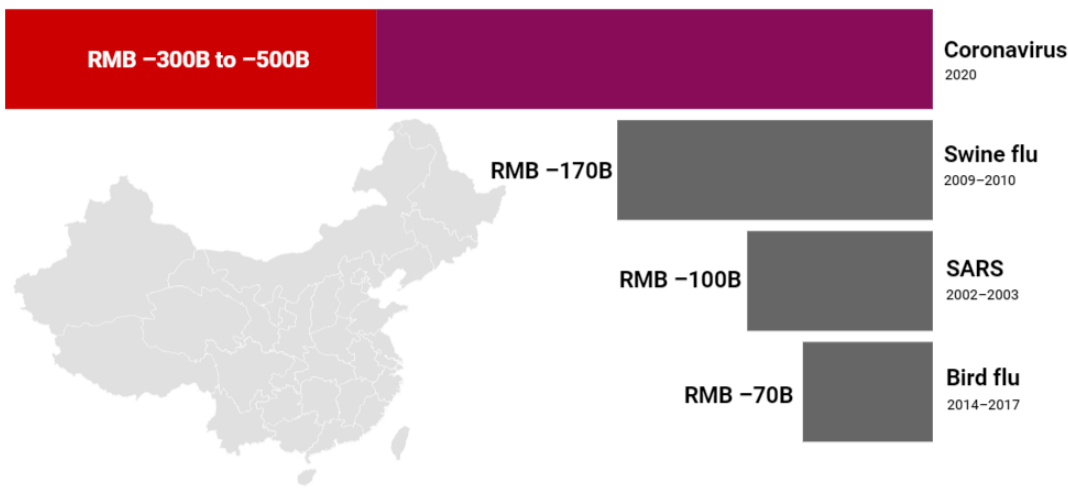

Figure 2. COVID-19 to cost China more than previous outbreaks (Han et al, 2020)

The blow of Covid-19 on China economy is going to be 5 times more severe than SARS due to a bigger share of the global economy now (16\%) than then $(4 \%)$ with $96 \%$ of its GDP contributed by industries focused on manufacturing and services than $85 \%$ in $2002 / 3$.

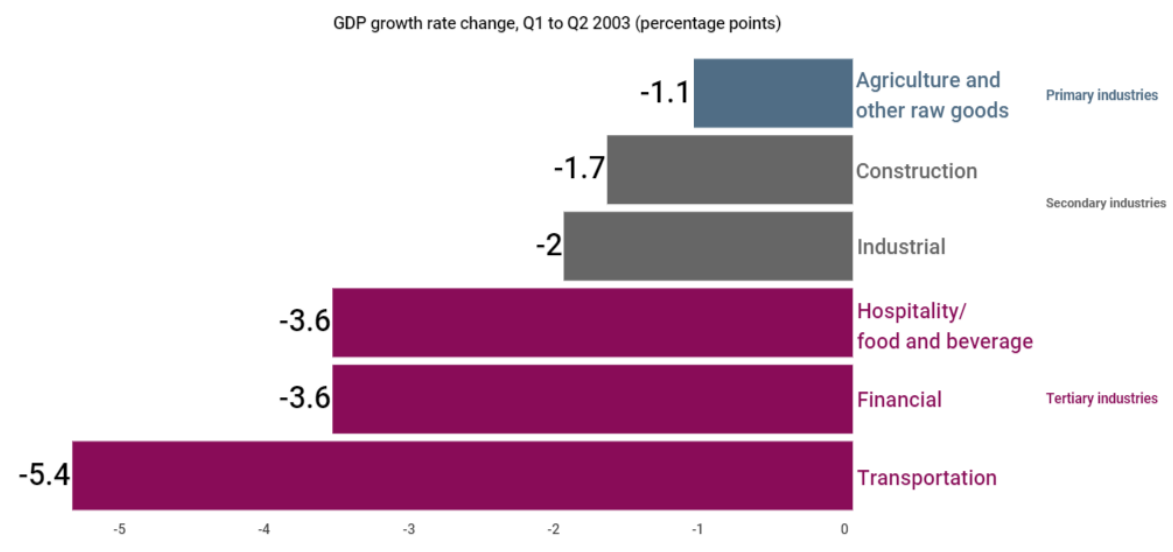

Figure 3. Lessons from SARS: These industries and sectors were hit hardest (Han et al, 2020)

Similar to COVID-19, the primary reactionary focus of government during SARS was the safety of its people. Lockdowns and MRO will have downward effect across industries from primary to tertiary. Current situation adversely affects the hospitality, transportation, fashion and alike industries that have recorded $25 \%$ shrink in revenue, which is equal to 3 months' worth of sales (Becker, 2020). For companies that are in the micro, small and medium enterprise category, this reduction defines their existence. Large percentage of them have short runway where they function on daily or weekly cash flows and will be out of business in weeks if not couple of months (Bedi, 2020). 


\section{RESULTS AND DISCUSSION}

\section{A. Malaysia Outlook}

World Bank cautioned two-thirds of 75 million travel and tourism industry jobs are in Asia.The following industries in Malaysia are already on the lost trajectory such as transport, hospitality, food and beverage (namely dine in), agriculture, commercial banking, construction-real estate, automotive and nonessential services (World Bank Group, 2020). There may not be permanent losers in post COVID-19 business world if businesses could extend their runway for the duration of MCO. However,startups in the country and individuals are already feeling the immediate impact of the MCO.

An e-survey conducted by The Star Publicationbetween 23 to 31 March 2020, showed 95\% selfemployed Malaysians experience drop in income with 35\% of them experiencing income drop of more than 90\%. $82 \%$ of the self-employed Malaysians and $71 \%$ of Malaysian employers are not financially ready if MCO were to be extended.To their fear, the MCO has been extended to another 2 weeks starting $14^{\text {th }}$ April 2020 and is expected to be extended further should situation remain volatileand uncertain (Bedi, 2020).

On the other hand, employees of GLCs \& MNCs are least affected as they have savings that could last them for 4 months (Bedi, 2020). MNCs \& GLCs are taking "wait and see" approach and the effect of Covid19 could only be partially or fully realized in months to come once the negative impact of the supply chain disruption kicks in.This will be influenced by efforts to cut oversupply in essential industries such as oil \& gas to keep their prices afloat. The current low oil price may be short lived till Q4 of 2020, increasing operational cost of key industries affected by COVID-19 such as transportation/aviation to record further lost in revenue. Similarly the drop in currency exchange will further aggravate the situation (Barbosa et al., 2020).

\section{B. Innovation Must Accelerate}

This disruption will further place pressure on Malaysia to become a "producer" of innovation that being complacent as mere "consumer" of innovation. COVID-19 provided an opportunity for the country to quickly realiseits potential in the realm of innovation. Malaysians from all walks of life have come together during this trying time with innovative methods to reinforce the healthcare with Personal Protective Equipment (PPE) for frontline personnel such as face shields, boots and gowns, laboratory made hand sanitizers and e-services (Dartnell, 2020).

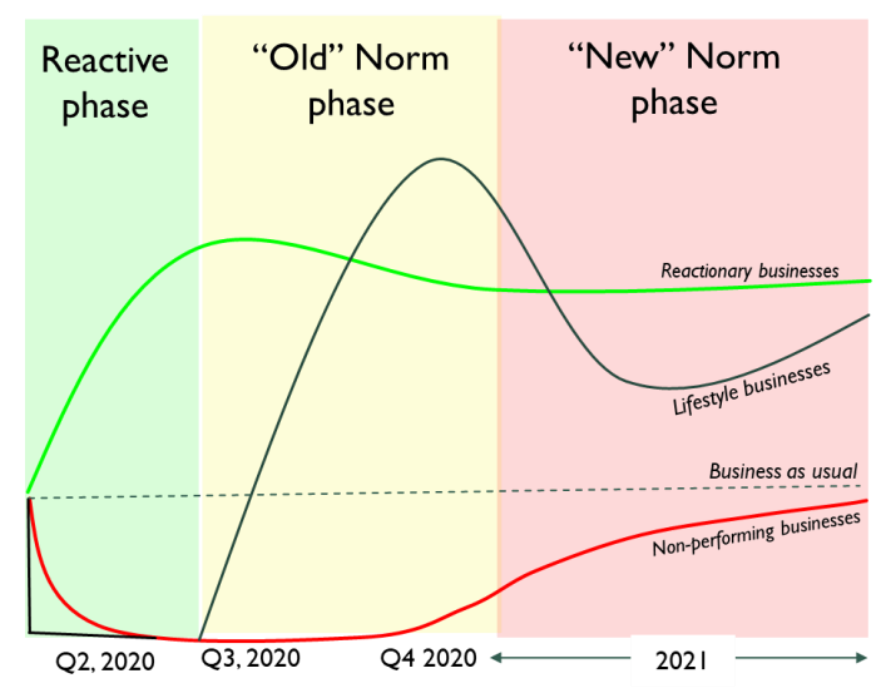

Figure 4. COVID-19, Business Growth over 2020 and 2021

Figure 4 shows three (3) phases of business shift due to behavioural changes of the people. The green graph indicated business that accelerate during the reactive phase and plateauing in the later phases. The res graph indicated conventional business that will accelerate upon the lifting or relaxation of MCO or lockdown and plateauing in the later phase. The black graph reflects the losers in the COVID-19 world. These businesses are expected to record losses for a longer period of time before rising. This rise may not be bring the businesses back to its pre-COVID-19 times unless operational innovation is done. 
Immediate need and opportunity have provided reactionary (green graph) businesses/products to gain traction such as PPE (gloves, face mask and sanitizers), packaged food, dry food items (longer shelf life), pet food, toilet papers, vitamins, cloud services, online shopping \& communication apps and regular medicines.

Once the lockdown or MCO is lifted or relaxed, there will be exponential increase (black graph) in services such as self-care, food and beverages, private \& e-hailing travel, private education, healthcare (nonacute/chronic), fashion \& lifestyle, recreation to a certain extend and innovation that uplifts safety. People during this phase are in the "state of denial", resisting change and trying hard to get back to their old (preCOVID-19) norm.

Industries that may see a longer runway before lifting off would be insurance, oil \& gas, aviation, hospitality and tourism (red graph).Nevertheless, this graph will be influenced by employment rate, recession, and government long term economic stimulus plan. These will influence purchasing power of people especially when they start to feel the loss or stagnation of income. This will slow down many nonessential business in the "old" norm phase and spur accelerated/exponential growth of businesses connected to digital economy .

\section{Looking Closer to Home: Globalization to Localization}

There will be a shift to cultivate bottom up home-grown innovation with a focus to build social resilience and safety. These businesses will enable the country to get back on its feet while building selfsustenance and economy durability (Dartnell, 2020).

Table 1. Winners and Losers at different phases of COVID-19 world

\section{“Old” Norm phase}

Reactive phase
(State of denial-resisting

change)
"New" Norm phase

(Resilience \& Safety) e-commerce (essential items) to experience steep growth during this phase

\section{$\checkmark$ Delivery services}

$\checkmark$ Neighborhood/local/ho me businesses

$\checkmark \quad$ Increased interest selfsustenance such as bread maker machine urban agriculture

$\checkmark \quad$ Online tools for education and businesses (remote communication \& collaboration)

$\checkmark \quad$ Social assistance

$\checkmark \quad$ Crowd sourcing and crowd funding einitiatives
Self-care (beauty \& grooming)

$\checkmark \quad$ Entertainment \& Events

$\checkmark \quad$ Food and Beverages (with focus on dine in)

$\checkmark \quad$ Shopping mall

$\checkmark \quad$ Public and Private Space planning (make shift \& adaptive reuse models)

$\checkmark \quad$ e-medicare

$\checkmark \quad$ Private education

$\checkmark \quad$ Local tourism-domestic holidays

$\checkmark \quad$ Real estate- pre Covid19 arrangements moves on
Neighbourhood and home agro farms

$\checkmark$ Home/cloud kitchens \& delivery

$\checkmark$ AI to continue social distancing, screening, tracking and disinfection (in all sectors)- mobile appand automation (micro-machineries for SME, robotics, sensors etc)

e-schooling (home schooling included), e-office and e-entertainment in the interest of safety (e-platform in general)

$\checkmark \quad$ Enhanced \& expanded e-services both government and private

Distributed business wealth across SM $\&$ Micro Enterprise to reduce overheads and operation cost of big corporations

$\checkmark \quad$ Increased investment in medical supply-response, biosafety/biosecurity biomedical, smart biotechnology R\&D and businesses 


\section{CONCLUSION}

While the origin of the pandemic is from outside of Malaysia, It cannot be denied that in the highly interconnected world, a nation like Malaysia can never stay in isolation. Malaysia needs the rest of the world for various reasons such as technological and knowledge transfer on top of trade. COVID-19 pandemic has created a new reality and this new reality demands the business world to embark on an accelerated shift towards being innovative, digital, pro-active and pre-emptive. The resilience built from this shift will determine the livelihood of regular people that hangs in the balance at the end of the spectrum while also enforcing durability to face potential future pandemic.

\section{REFERENCES}

Barbosa, F. et al. (2020) Oil and gas after COVID-19: The day of reckoning or a new age of opportunity?, McKinsey. Available at: https://www.mckinsey.com/industries/oil-and-gas/our-insights/oil-and-gasafter-covid-19-the-day-of-reckoning-or-a-new-age-of-opportunity\# (Accessed: 20 October 2020).

Becker, E. (2020) How hard will the coronavirus hit the travel industry?, National Geographic. Available at: https://www.nationalgeographic.com/travel/2020/04/how-coronavirus-is-impacting-the-travel-industry/ (Accessed: 20 October 2020).

Bedi, R. S. (2020) MCO: Almost 50\% of self-employed Malaysians out of work, survey finds, The Star. Available at: https://www.thestar.com.my/news/nation/2020/04/09/mco-almost-50-of-self-employedmalaysians-lost-their-jobs-survey-finds (Accessed: 20 October 2020).

Dartnell, L. (2020) The Covid-19 changes that could last long-term, BBC Future. Available at: https://www.bbc.com/future/article/20200629-which-lockdown-changes-are-here-to-stay (Accessed: 20 October 2020).

Erken, H. (2020) Global Economic Outlook: COVID-19 has taken a hold of the global economy RaboResearch RaboBank. Available at: https://economics.rabobank.com/publications/2020/march/global-economic-outlook/ (Accessed: 20 October 2020).

Han, W., Harris, K. and Luedi, T. (2020) How Much Will Coronavirus Hurt China's Economy?, Bain \& Company. Available at: https://www.bain.com/insights/coronavirus-impact-china-gdp-snap-chart/.

Meier, A. (2009) Panacea, Curse, or Nonevent? Unconventional Monetary Policy in the United Kingdom; by. London.

Rayda, N. (2020) Indonesian President Jokowi announces large-scale social restriction and emergency status to curb COVID-19, CNA. Available at: https://www.channelnewsasia.com/news/asia/indonesiajokowi-emergency-large-scale-social-restriction-12594190 (Accessed: 20 October 2020).

WHO (2020) World Health Organization, Who. Available at: https://www.who.int/ (Accessed: 20 October 2020).

World Bank Group (2020) Covid-19 Policy Response Notes For Vietnam, Public Disclosure Authorized. Available at: https://openknowledge.worldbank.org/bitstream/handle/10986/33998/COVID-19-PolicyResponse-Notes-for-Vietnam-Compilation.pdf?sequence $=1$ \&isAllowed $=y \quad$ (Accessed: 20 October 2020). 